\title{
Technological convergence and innovative development of natural resource economy
}

\author{
Felix Agafonov ${ }^{1, *}$, Anton Genin ${ }^{2}$, Oksana Kalinina ${ }^{3}$, Olga Brel $^{4}$, and Olga Zhironkina ${ }^{5}$ \\ ${ }^{1}$ T.F Gorbachev Kuzbass State Technical University, Post-Graduate Study, 650000 Kemerovo, 28 \\ Vesennya st, Russia \\ ${ }^{2}$ Branch of JSC "SO EES” Siberian ODU 650000, Kemerovo, 29 Kuzbasskaya st., Russia \\ ${ }^{3}$ T.F Gorbachev Kuzbass State Technical University, Department of History, Philosophy and Social \\ Sciences, 65000 Kemerovo, 28 Vesennya st, Russia \\ ${ }^{4}$ Kemerovo State University, Department of Geology and Geography, 6500006 Krasnaya st., \\ Kemerovo, Russian Federation \\ ${ }^{5}$ Plekhanov Russian University of Economics, Kemerovo Branch, Department of Humanities, 650992 \\ Kemerovo, 39 Kuznetsky Av., Russia
}

\begin{abstract}
An integral component of the innovative development of natural resource economy is the integration of technological solutions and investments in industrial production, the expansion of national manufacturing complex in the world market with the following change in the export structure. Implementation delay of convergent technologies may lead to the loss of Russian technological identity, strengthening raw vector of longterm social and economic development. In this regard, the relevance of the study of problems and obstacles to the implementation of convergent technologies in the economy of countries which specialize in production and export of mineral resources is increasing. To start the innovative development in Russian economy it is important to restore the dominance of modern industrial complex in it. This will lead to the decrease of pre-industrial economy and will contribute to the formation of post-industrial technological layer. Therefore, convergent and technological transformation of natural resource economy is imposed with the strategic task of improving profitability, investment attractiveness and international competitiveness of industrial production.
\end{abstract}

\section{Introduction}

In the course of market reforms some basic principles of innovative development of Russian economy had been violated. They are: the priority of modernization of production basis and transformation of economic relations towards neo-industrialization, the integrated use of program-target and market forms of regulation of the business sector by the government in accordance with the depth of structural problems.

As a result, Russian economy has rental-resource model of development. It allows, on the one hand, achieving short-term budget macroeconomic goals, but does not contribute to the economic development through the sequence change of technological layers. As a re-

\footnotetext{
* Corresponding author: kemshi-ise@mail.ru
} 
sult, in mineral resource economy investments with short-term effects connected with conjunctions of commodity and financial markets dominate over the long-term investments leading to the change of technological layers.

\section{Material and method}

The driving forces of innovative development of economy - the development of economic relations in terms of investments, innovations, the labor market, in cooperation between the state and business in Russia are restrained by a number of pro-problems [1, 2, 3]:

a) The uncertainty of the "rules of the game" for the subjects of high-tech-industries, innovative sphere, advanced processing of raw materials in economy, in which the major part of government and private sector revenues is based on the extraction and redistribution of mineral resource rent. Under these circumstances of institutional "vacuum" and high entropy of the commodity market, uncertainty and risks of investment the technological level of production, new demand for the labor force, the labor itself are repeatedly increasing;

b) Significant underfunding by the state the fundamental researches - the first stage of innovative process, ensuring the development of current and start of the future technological layers. For example, in 2010-2013 public financing of fundamental and applied science in Russia amounted to $0.2-0.3 \%$ of GDP, in the USA - 2.7\%, in France - 3.5\% [4];

c) The lack of the $6^{\text {th }}$ technological layer experimental "production facilities", allowing to carry out applied research and experimental production. Existing in Russia technological platforms, funded mainly by the state, are concentrated in the sectors of the $5^{\text {th }}$ technological layer, and the business does not have an appropriate effect on their development. In Russia R\&D is funded by the state on $75-80 \%$, while in the USA and the EU countries on $20-25 \%$ where the rest part falls on the business [4];

d) Generated in Russian technological platforms innovations do not reach mass production, and the large enterprises in clusters of innovative development continue to produce traditional products, including raw materials. The share of innovative output produced by coal and metallurgical enterprises of Kuzbass cluster does not exceed 1\% of their output, by machine-building enterprises of Altai cluster - 3\%, petrochemical enterprises of Tatarstan 4\%. Among Russian small firms only 1\% compared with $9 \%$ in the USA and $8 \%$ in France is engaged in innovative activity, while the volume of venture capital investment in these countries in 2012 amounted $0.73,29.5$ and 1.2 billion dollars respectively [5];

e) Existing Russian innovative tax advantages do not attract investors in the most advanced technologies of the $6^{\text {th }}$ technological layer and scientific-production special economic zones contribute very little to their implementation in mass production [6-8]. Also Russian tax system does not support innovation development of environmental saving technologies [9-10].

f) There is no state support for the production and promotion of technologically advanced, innovative products in the domestic and foreign markets (subsidies, lobbying, and government investment in the companies of the $6^{\text {th }}$ technological layer). Meanwhile, today, the majority of Russian innovative clusters have public-private partnerships allowing coordinate the actions of the state and business in bringing research results to innovation [1112]. However, by themselves they cannot remove a significant obstacle in modernization process of Russian economy - the gap between innovation and mass production to overcome which the massive system changes in reproduction, industry, market-competition, institutional structures are required. 


\section{Results and discussion}

To solve these problems it is necessary to identify a number of areas for implementation the principle of active participation of the state in the structural transformation of natural resource Russian economy:

1. Bringing the system of formal and informal institutions in compliance with the requirements of neo-industrial structural changes, interaction harmonization of institutions of the state and the market in order to eliminate barriers and protect the interests of high-tech companies in the domestic and foreign markets.

2. The transition from the fragmented support of public research organizations, public companies in defense sector to the broad arrangement of preferential conditions for private investments in innovation, particularly in the field of breakthrough technologies.

3. The involvement of financial capital movement in the modernization process of industrial production, the reorientation of investments from the financial market into the innovative sphere, the transformation of property relations in the process of vertical integration of raw material, manufacturing industry and the scientific sector, the use of emission mechanism for the financing of the most competitive technologically advanced industries.

4. Changing the role of state ownership in economy and its gradual withdrawal from raw material and financial sectors and the reorientation to high-tech industries.

5. Promotion of innovative initiatives on the labor market, changing relations associated with staff hiring and wages in the direction of the full motivation of in-house innovation process, employees' participation in the creation, investment and promotion of innovations.

6 . Reducing the investment and innovative risks of technological industry modernization placing high demands for production structure of fixed capital, the level of its depreciation.

7. The encouragement of effective demand for domestic goods and services of manufacturing and high-tech industries and the development of their import substitution.

The basis of structural transformation of natural resource Russian economy includes a system and multi-subject nature of its structural reforms, the combination of normative, indicative regulation and market self-regulation, the presence of neo-industrial attractor, goal setting and strategic programming taking into account the depth of the structural problems that impede neo-industrialization of economy, import substitution development and formation of the target social group. The advanced subjects of national innovation system, first launched in the European Union, are technological platforms that integrate business, science and the government. The European Commission understands technological platforms as the directions of cooperation among universities, innovative companies and large manufacturers. It is in these areas public funds for fundamental and applied research are allowed. The main feature of the technological platforms of the EU is the participation of not only scientific organizations and industrial companies, but also banks, investment companies, European concerns. The state participation in technological platform is not limited by direct financing, but includes government guarantees, government investments, leasing and credit subsidies. The initiators of the European technological platforms creation are the so-called sectoral associations of industrial corporations - High Level Groups.

Since the beginning of the 2000s the EU has created more than 40 technological platforms (including 26 - in sectors of the $6^{\text {th }}$ technological layer, such as «Future Manufacturing Technologies», «Embedded Computing Systems», and «European Nano-electronics Initiative Advisory Council» working for more than 10 years) [13]. National Support Groups of technological platforms are being founded in the European Union countries. They bring together leading scientists and officials and fulfill the following tasks:

- technological breakthrough in high-tech industries;

- the development of new processing chains in the traditional raw material sectors; 
- the development of new sectors of economy by overcoming the fragmentation of science and lack of structuring of business interests.

In Russian economy the development of technological platforms began only in 2011 on the initiative of the Russian Government. Government Commission on High Technologies and Innovations approved about 30 platforms [14], the founders and coordinators of which were industrial companies, the government research institutes and state corporation "Rosnano", "Rostechnologii" [15-16]. It is obvious that Russian technological platforms do not follow the main condition of their participation in economy neo-industrialization - providing technological breakthrough (the latest technologies of the $6^{\text {th }}$ layer) required for outgoing to the path of innovative development. On the contrary, they involve basic and extractive industries such as power industry, transport, mining, metallurgy, chemistry, construction [17]. And in industries that can widely use high technologies (biochemistry, photonics, manufacturing materials with special nano-properties and supercomputers), only a few platforms were formed. Financing the innovative enterprises in these industries, which are mostly state-owned, is directly made by the state, without motivating business to participate in this process. Therefore, we consider further development of cooperation links between producers and processors of raw materials on the one hand and high-tech firms on the other on the basis of techno-platforms to be necessary. The development of high-tech service industries specific for neo-industrial economy (the $5^{\text {th }}$ technological layer) requires massive public and private investments in the creation of new and the development of existing techno-platforms (especially bio-technological, information and communication).

But as in Russian economy massive private and corporate investments in high-tech sector are almost absent, there are underdeveloped investment ties, scientific and industrial cooperation capable to alter the territorial structure of the productive forces. The potential use of innovative clusters in Russian economy neo-industrialization is not enough.

The issues of structural convergence (a special type of structural changes in the course of which new forms of network and cluster structures can be formed, and in future - new industries) were considered by M.A. Gasanov. It must be based on digitization of most production processes of material and non-material values. It means changing of technical, administrative, financial processes into a single digital format clear for modern computers, eliminating the differences between various types of information.

Today, convergent technologies are the subject for study of biologists, physicists, chemists, experts in the field of information technologies and micro-robots. We define the development of convergent technologies as an important technological condition of innovative development of Russian economy in the process of its structural changes.

The content of technologies' convergence consists in the interpenetration and combination of different innovations, united by a common digital form of designing, printing and diffusion. Also, technological convergence means the development multi-platform innovations in existing clusters, developed in different technological platforms, but able to give a united product. We have identified the following areas of convergent technologies development:

- Technologies at the interface of biochemistry and energy (bioenergy), allowing in the nearest future, move to the non-waste production of environmentally clean fuel replacing non-renewable hydrocarbon resources. The development prospects of these technologies we see in the cross-platform interactions of such techno-platforms as "Medical and biotechnologies", "Power industry", "Extraction of natural resources and oil and gas processing";

- Technologies that connect the manufacturing of processor equipment and software (distributed computing). They will be able to create an integrated telecommunication networks, significantly advance the diagnostic medicine, and accelerate the creation of new equipment by computational design and multi-factor computer simulation. Their cross- 
platform character should be revealed in the interaction of such techno-platforms as "Information and Communication Technologies", "Electronics and Machine Building";

- Laser informatics technologies that can create data depositories, surpassing modern ones in thousands of times. This will speed up the digitization of technological basis of industry, initiate robotics of such traditional for Russia industries as coal, oil and gas, chemical, heat power industry. Cross-platform relations here can be implemented in such platforms as "Photonics", "Information and Communication Technologies".

\section{Conclusions}

Implementation of convergent and technological conditions of innovative development of Russian economy is restricted by a vicious circle of problems in which the business does not have an attractive innovation investment technological basis, and the development of convergent technologies is constrained by the lack of strategic interaction of the state and business. To solve the problems of innovative development of Russian economy and to move from the natural resources export to the production of high-tech products it is necessary to increase investments in fundamental research, the development of connections between R\&D and production, the participation of banks and investment companies in the innovation financing, the staffing of the innovative process.

\section{References}

1. A. Zhavoronok, M. Gasanov, S. Zhironkin, SHS Web of Conferences, 28, 01144 (2016)

2. M. Gasanov, S. Zhironkin, M. Hellmer, EpSBS, XIX, 745 (2017)

3. S. Zhironkin, M. Gasanov, O. Zhironkina, EpSBS, XIX, 753 (2017)

4. M. Gasanov, S. Zhironkin, EpSBS, VII, 117 (2016)

5. A.A. Baryshev, G.A. Barysheva, EpSBS, VII, 352 (2016)

6. S. Zhironkin, M. Gasanov, O. Zhironkina, EpSBS, VII, 124 (2016)

7. S. Zhironkin, V. Guzyr, EpSBS, VII, 160 (2016)

8. V. Trifonov, O. Loyko, D. Nesteruk, S. Zhironkin, E. Strekovtsova, AIP Conf. Proceed., 1800, 050009 (2017)

9. M.A. Tyulenev, Y.V. Lesin, Taishan academic forum - Project on mine disaster prevention and control, 441 (2014)

10. Yu.V. Lesin, S.Yu. Luk'yanova, M.A. Tyulenev, J. Min. Sci., 46:1, 78 (2010)

11. S. Zhironkin, E. Gasanov, O. Zhironkina, E. Taran, SHS Web of Conferences, 28, 01145 (2016)

12. S. Zhironkin, M. Gasanov, K. Kolotov, EpSBS, XIX, 761 (2017)

13. S.A. Zhironkin, K.A. Kolotov, A.E. Genin, F.V. Agafonov, S.A. Kovalevsky, IOP Conf. Ser.: Earth Environ. Sci., 50, 012011 (2017)

14. M. A. Tyulenev, S. A. Zhironkin, E.A. Garina, Int. J. of Mining and Mineral Engineering, 7:4, 363 (2016)

15. M.A. Tyulenev, T.N. Gvozdkova, S.A. Zhironkin, E.A. Garina, Geotech. Geol. Eng., 35, 203 (2017) 
16. M. Tyulenev, E. Garina, A. Khoreshok, O. Litvin, Y. Litvin, E. Maliukhina, IOP Conf. Ser.: Earth Environ. Sci., 50, 012035 (2017)

17. M.Y. Blaschuk, A.A. Dronov, S.S. Ganovichev, IOP Conf. Ser. Mater. Sci. Eng., 142, 012128 (2016) 